Journal of Health Promotion and Behavior (2019), 4(3): 178-188

https://doi.org/10.26911/thejhpb.2019.04.03.03

\title{
Risk Factors of HIV among Male Military Personnels: A Meta Analysis
}

\author{
Ayu Anulus'), Bhisma Murti1), Hanung Prasetya' ${ }^{2)}$ \\ 1)Masters Program in Public Health, Universitas Sebelas Maret \\ ${ }^{2)}$ Study Program of Acupuncture, School of Health Polytechnics, Ministry of Health, Surakarta
}

\begin{abstract}
Background: Military personnel has a high risk of being exposed to HIV. The transmission of HIV from male military personnel is like an iceberg phenomenon. Based on studies in the US, UK, and France, the military personnel from these countries are much more likely to be contaminated with HIV than the equal age/sex group in the civilian population. This study aimed to analyze the risk factors of HIV among male military personnel by using meta-analysis.

Subjects and Method: This study was a systematic and meta-analysis study. The articles used in this study were obtained from several electronic databases including PubMed, Scopus, Springer Link, ScienceDirect, and Clinical key. These articles were collected for 2 weeks. The keywords used in searching for the articles were as follows: "HIV", "soldier", "military", "armed force", "army", "navy", "air force", "armed force", "sex partner", "man having sex with man (MSM)", "homosexual", number of marriage","prostitute","sexually transmitted infection (STI)", and "conscription". The articles included in this study were full-text articles with cross-sectional design. The articles were collected using PRISMA flow diagram. These articles were analyzed using meta-analysis with the Review Manager 5.3 application.

Results: $\mathrm{MSM}(\mathrm{aOR}=9.37 ; 95 \% \mathrm{CI}=5.31$ to $16.55 ; \mathrm{p}<0.001)$, sexually transmitted infections (aOR $=3.75 ; 95 \% \mathrm{CI}=3.00$ to $4.68 ; \mathrm{p}<0.001)$, sexual partners $>10(\mathrm{aOR}=3.05 ; 95 \mathrm{CI}=2.12$ to 4.38 ; $\mathrm{p}<0.001$ ) increased the incidence of HIV among male military personnel, and it was statistically significant. Sex with CSWs ( $\mathrm{aOR}=3.93 ; 95 \% \mathrm{CI}=0.93$ to $16.62 ; \mathrm{p}=0.060)$ increased the incidence of HIV among male military personnel, but it was not statistically significant.

Conclusion: MSM, STI, and sexual partners $>10$ increase the incidence of HIV among male military personnels.
\end{abstract}

Keywords: HIV, MSM, commercial sex workers, sexually transmitted infection, CSW, military

\section{Correspondence:}

Ayu Anulus. Masters Program in Public Health. Universitas Sebelas Maret. Jl. Ir. Sutami 36A, Surakarta 57126, Central Java, Indonesia. Email: anulusayu@gmail.com. Mobile: 082359056395.

\section{BACKGROUND}

Based on UNSAID data (2018), 47\% of new HIV infections globally in 2017 were among key populations and their sexual partners. Key populations and sexual partners contributed for more than 95\% of new HIV infections in Eastern Europe, Central Asia, the Middle East, and North Africa. There were $90 \%$ of new infections in Western Europe, Central Europe, and North America. There were $77 \%$ of new infections in Latin America and 84\% in Asia, the Pacific and the Caribbean. As many as $40 \%$ of new HIV infections were among key populations and sexual partners in West and Central Africa.

The majority of people living with HIV are in their working or productive age (ILO, 2018). Men who have sex with men (MSM) contributed to around 57\% of new HIV infections in Western Europe, Central Europe, and North America. Sex workers contributed about one of 10 infections in Eastern Europe, Central Asia, the Middle East, and North Africa (UNAIDS, 2018). 
Military personnel has a high risk of being contaminated with sexually transmitted diseases, including HIV. Military health authorities in Ethiopia believe that the warriors/fighters who were contaminated with HIV to their communities and went home after the Eritrean war of independence in 1991 was an important transmission factor in HIV epidemic in Ethiopia (Kenny et al., 2010). During peacetime, the level of sexually transmitted disease infection among the armed forces was generally 2 to 5 times higher than the civilian population. Based on studies in US, UK, and France, military personnel of these countries had much more likely to be contaminated with HIV compared to an equal age/sex group in the civilian population. The latest rate from Zimbabwe and Cameroon showed that the level of HIV infection in military was 3 to 4 times higher than the civilian population (UNA-IDS, 1998; Jadranin et al., 2012).

The military population is susceptible to do the behavior that is at risk of being contaminated with HIV. It occurs because it is supported by the working conditions. The conditions are living away from spouse, disobeying the limits of family and community behavior, affecting by peer pressure, having values that cause risky behavior, being paid and/or having money to buy things that related to sex, the possibility of being contaminated with blood through injury, direct contamination, or through transfusion (Whiteside et al., 2006). Military personnel who served for long periods of time generally tended to choose using CSWs in meeting the biological need. Basically, women who choose to become CSW have a positive correlation with lifestyle and access to prostitution localization (Johar et al., 2018).

Based on a study conducted by Courtney et al. (2017), the prevalence of military personnel who were contaminated with HIV virus while serving in the Sudanese people's liberation mission was $5 \%$ out of 1,063 military personnel studied. The highrisk behaviors found in this study were multiple or concurrent sexual partners, heavy alcohol consumption, and inconsistance condom use.

Other studies from Hoover et al. (2017) in the United States found that 4.23\% of male military personnel confessed that they were gay, bisexual, or having sex with men. One of the examples of behavior that is at risk of being contaminated with HIV among military personnel occurred in Uganda. The military personnel raped men and women, while rebel militias were accused of kidnapping children and forced to serve as commanders' wives (Kenny et al., 2010).

The HIV transmission from male military personnel is like an iceberg phenomenon. The case of HIV infection in military personnel is only half part of the problem. A much bigger problem is the threat of HIV virus transmission from the military personnel to the family members especially wives and the wider surrounding community. Most young people in many countries spend about a year or more in the military to participate in military service or voluntary participation. Therefore, the number of people who return to civilian life is very large both numerically and in its potential impact on all sections of society (UNAIDS, 2018).

The threat of HIV transmission by the military personnel supported by several studies encourages the researchers to combine and analyze the results of the existing study and draw the conclusion from studies that discuss behaviors that lead to the risk factors of HIV among male military personnel in the world. 


\section{SUBJECTS AND METHOD \\ 1. Study Design \\ This study was a systematic study and a meta-analysis. The articles used in this study were obtained from several electronic databases including PubMed, Scopus, Springer Link, ScienceDirect, and Clinical key. These articles were collected for 2 weeks. The keywords used in searching for the articles were as follows: "HIV", "HIV/ AIDS", "soldier", "military", "armed force", "army", "navy", "air force", "armed force", "sex partner", "man having sex with man", "homosexual", "number of marriage", "prostitute", "sexually transmitted infect- ion", and "conscription".}

\section{Inclusion Criteria}

The articles included in this study were fulltext articles with a cross-sectional design. The selected articles discussed the risk factors of HIV infection among male military personnel (sexual orientation status, number of sexual partners, having sex with CSWs, and STIs). The articles were published in English. The sample of the study was military personnel of army, navy, and air force. The data of study results were multivariate. The final result of the study was reported using adjusted odds ratio (aOR).

\section{Exclusion Criteria}

The articles that were excluded in this study were the articles with RCT study design, case-control, quasi-experiment, and study protocol. The articles were not published in English. The statistical results reported were not aOR.

\section{Operational Definition of Variables} HIV in male military personnel was an HIV infection that attacked the immune system in male military personnel such as army, navy, air force, and young group who followed conscription.

MSM was an emotional and sexual attraction between men and other men.

The number of sexual partners was the number of individuals who had sex with male military personnel.

Having sex with commercial sex workers was sexual contact in pairs with commercial sex workers.

Sexually transmitted infection was other infectious diseases that came from unhealthy sexual relation. The STIs were syphilis, herpes, chlamydia, gonorrhea, and bacterial vaginosis

\section{Data analysis}

The data processing was carried out using Review Manager (RevMan 5.3) by calculating the value of effect size and heterogeneity to determine the merged model of the study and form the final meta-analysis in Forest plot.

\section{RESULTS}

The process of searching for articles by searching through journal databases can be seen in Figure 1.

Figure 2 shows the area where the articles were published according to the inclusion criteria. They were across 3 continents, such as South America, Africa, and Asia. 


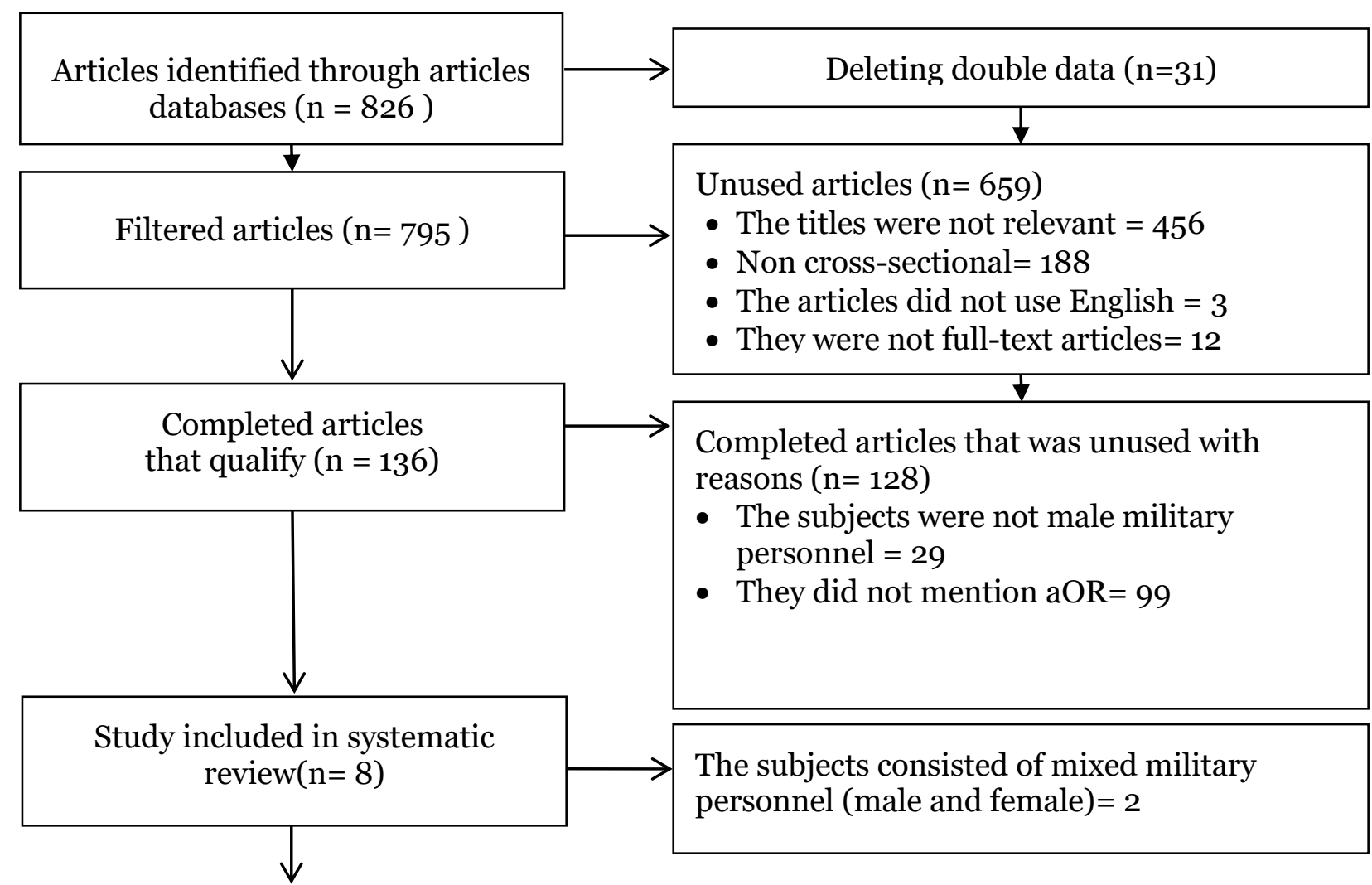

Study included in meta-analysis $(\mathrm{n}=6)$

Figure 1. The diagram of the review process flow

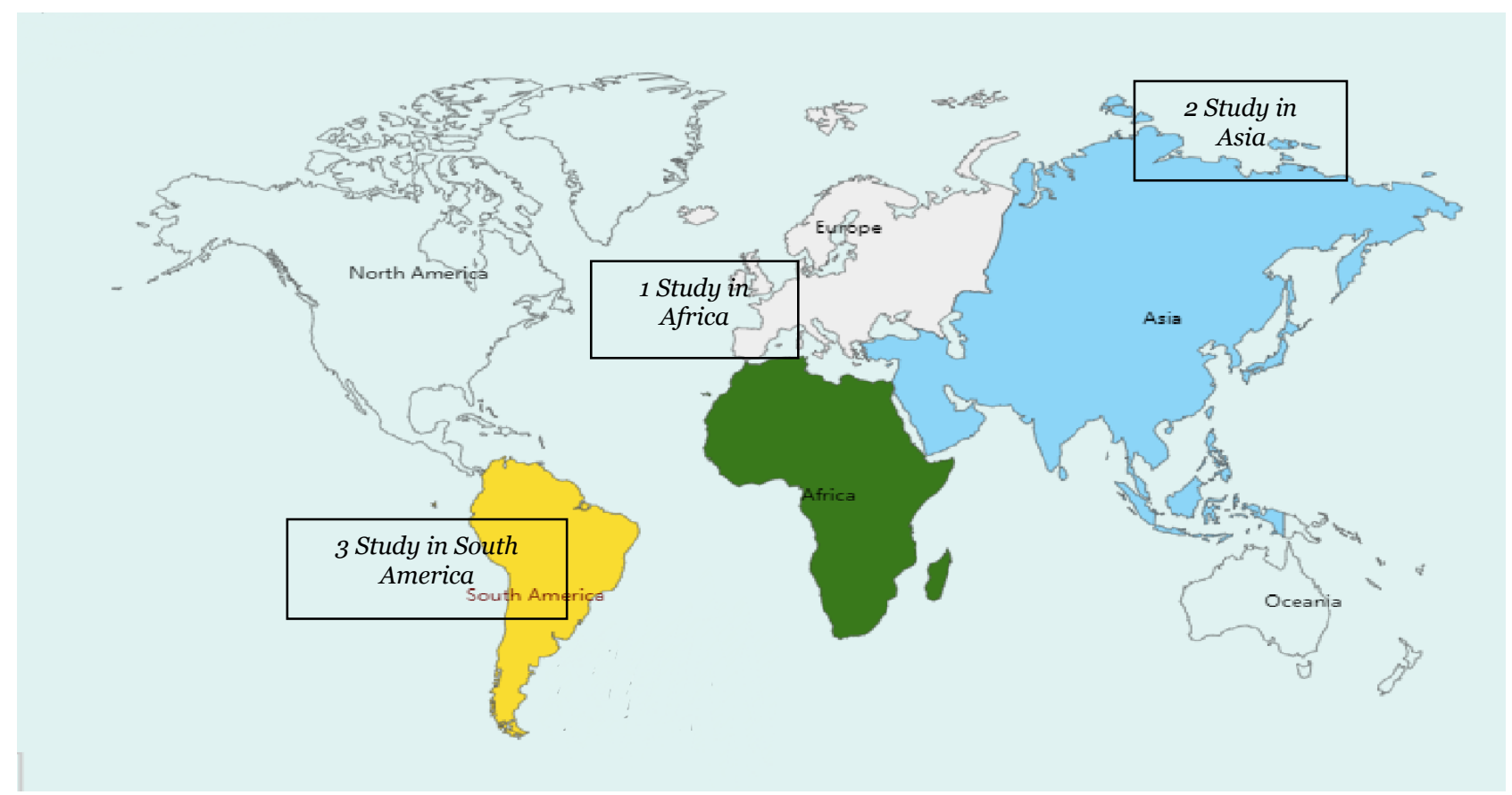

Figure 2. Map of the area of the study 
Journal of Health Promotion and Behavior (2019), 4(3): 178-188

https://doi.org/10.26911/thejhpb.2019.04.03.03

1. Men who have Sex with Men

Three cross-sectional articles proved that the status of MSM affected HIV among male military personnel in the world.

Table 1. The effect of the status of men who have sex with men towards HIV

\begin{tabular}{lcccc}
\hline \multicolumn{1}{c}{ Author (year) } & Country & aOR & 95\% CI & p \\
\hline Sperhacke et al.(2018) & Brazil & 14.62 & 4.94 to 43.25 & $<0.001$ \\
Szwarcwald et al.(2005) & Brazil & 4.06 & 1.29 to 12.80 & 0.002 \\
Szwarcwald et al.(2011) & Brazil & 11.16 & 4.91 to 25.40 & $<0.001$ \\
\hline
\end{tabular}

\section{b. Forest plot}

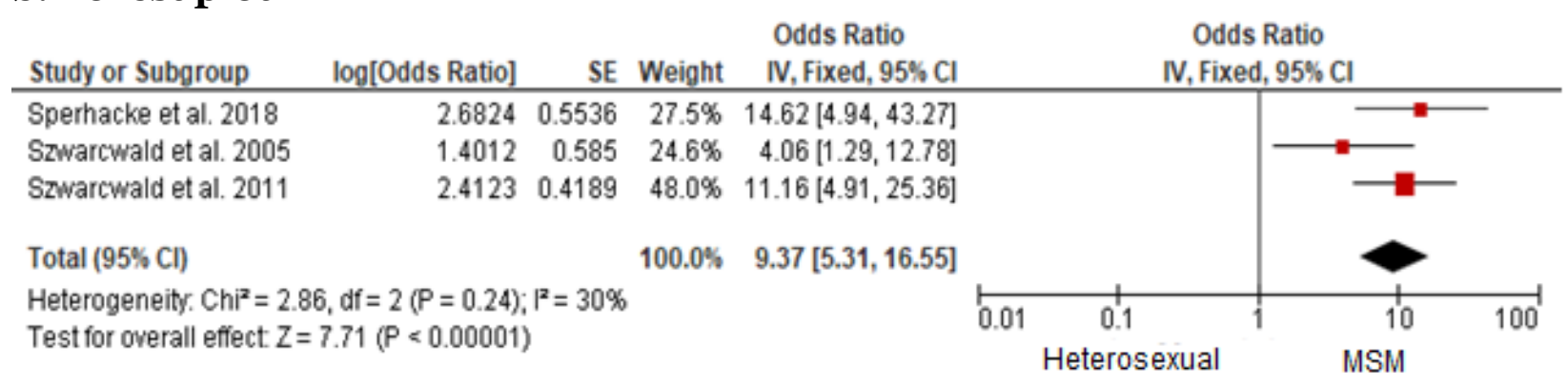

\section{Figure 3. Forest plot of sexual orientation of men who have sex with men towards HIV}

Based on the result of the forest plot, the status of MSM sexual orientation could increase the incidence of HIV in male military personnel by 9.37 times compared to heterosexual orientation status. The result was statistically significant ( $\mathrm{p}<0.001$ ). Heterogeneity $\left(\mathrm{I}^{2}\right)=30 \%$ indicated the homogeneous data distribution (fixed-effect model).

\section{c. Funnel plot}

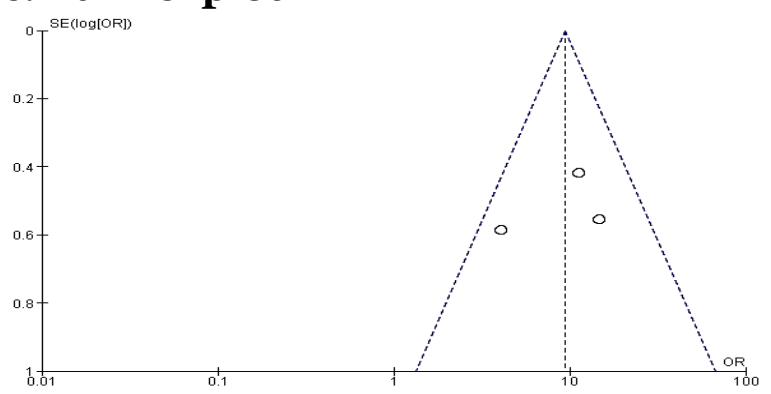

Figure2. The funnel plot of the status of MSM sexual orientation on the incidence of HIV
Figure 2 shows that there was a publication bias marked by an asymmetry in the right and left plots where there were 2 plots on the right and 1 plot on the left. The plot on the left of the graph had a standard error by 0.6 and all plots on the right have a standard error between 0.4 and o.6. Bias also occurred from unbalanced distance between studies, both the right and left sides, where studies on the left side had further distance than studies on the right side of the Funnel plot.

\section{The number of sexual partners}

There were 4 cross-sectional articles as the sources of meta-analysis that showed that the number of sexual partners was more than 10 on the incidence of HIV among male military personnel in the world. 
Table 2. The effect of the number of the sexual partner on the incidence of HIV that was $>10$

\begin{tabular}{lllcc}
\hline \multicolumn{1}{c}{ Author (year) } & Country & aOR & 95\% CI & p \\
\hline Sperhacke et al. (2018) & Brazil & 3.32 & 1.14 to 9.63 & 0.028 \\
Nelson et al. (1993) & Thailand & 3.78 & 2.17 to 6.58 & $<0.001$ \\
Szwarcwald et al. (2005) & Brazil & 2.33 & 1.05 to 5.18 & 0.037 \\
Szwarcwald et al. (2011) & Brazil & 2.52 & 1.21 to 5.25 & 0.013 \\
\hline
\end{tabular}

\section{b. Forest plot}

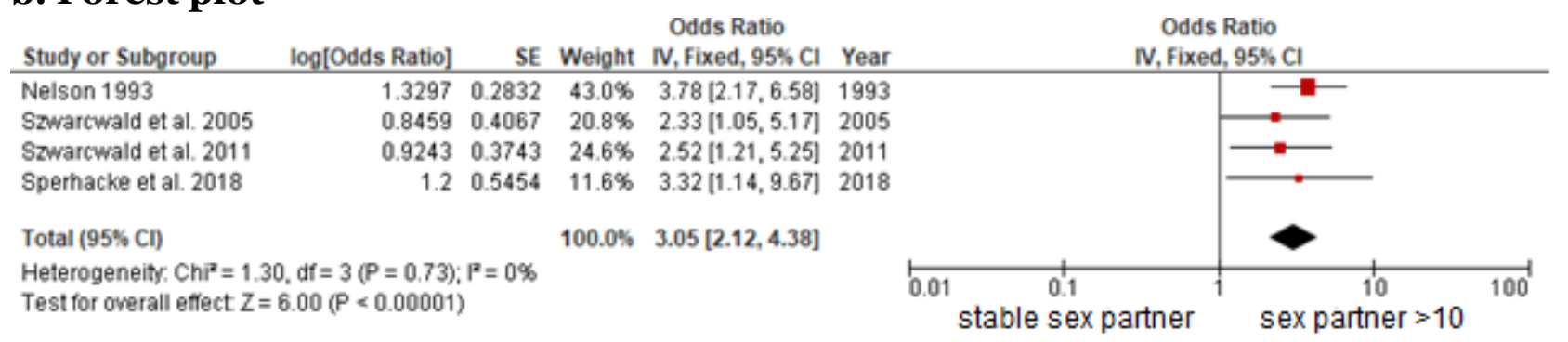

Figure 3. The forest plot of sexual partner $>10$ on the incidence of HIV

Based on the result of the forest plot, the number of sexual partners more than 10 could increase the incidence of HIV in male military personnel by 3.05 times compared to those with stable sex partner. The result was statistically significant $(\mathrm{p}<0.001) . \mathrm{I}^{2}=$ $\mathrm{o} \%$ indicated homogeneous data distribution.

\section{c. Funnel plot}

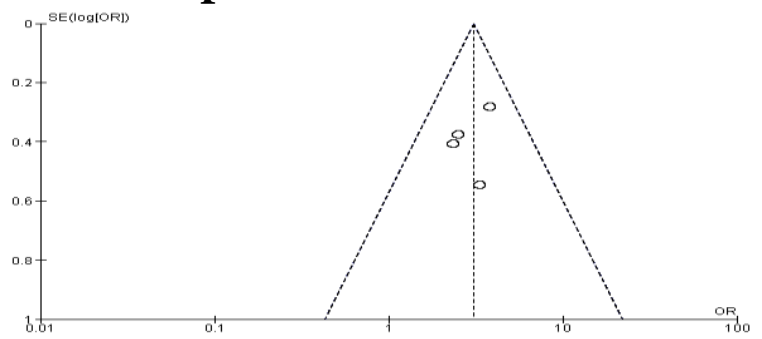

Figure 4.The funnel plot sexual partners $>10$
Figure 4 shows that there was no publication bias. The absence of publication bias could be seen from the balance of the right and left plots. All studies on the left of the graph had a standard error that was close to o.4. In addition, all studies on the right had a standard error between 0.2-0.6.

\section{Having sex with commercial sex workers}

There were 2 cross-sectional articles that showed the effect of having sex with CSWs on the incidence of HIV among male military personnel in the world.

Table 3. The effect of having sex with CSWs on the incidence of HIV

\begin{tabular}{llllc}
\hline \multicolumn{1}{c}{ Author (year) } & Country & aOR & \multicolumn{1}{c}{ 95\% CI } & p \\
\hline Nelson et al. (1993) & Thailand & 2.07 & 1.33 to 3.22 & 0.001 \\
Khamboonruang et al. (1996) & Thailand & 9.14 & 2.86 to 29.20 & $<$ 0.001 \\
\hline Based on the result of the forest plot, ha- & CSWs. However, the result & was not \\
ving sex with CSWs could increase the inci- & statistically significant (p=0.060). I I $^{2}=82 \%$, \\
dence of HIV in male military personnel by & \multicolumn{2}{l}{ so that the data distribution was heteroge- } \\
3.93 times compared to not having sex with & neous (random effect model).
\end{tabular}




\section{b. Forest plot}

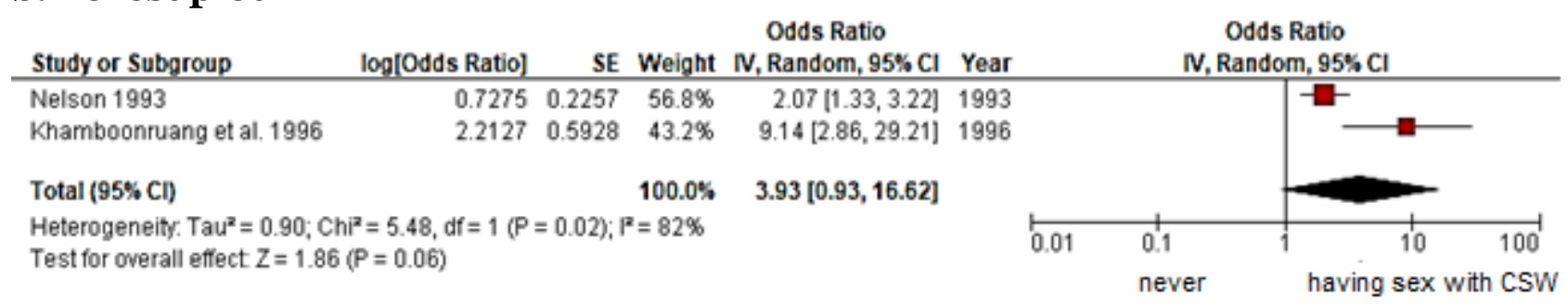

Figure 5. The forest plot of having sex with CSW on the incidence of HIV

\section{c. Funnel plot}

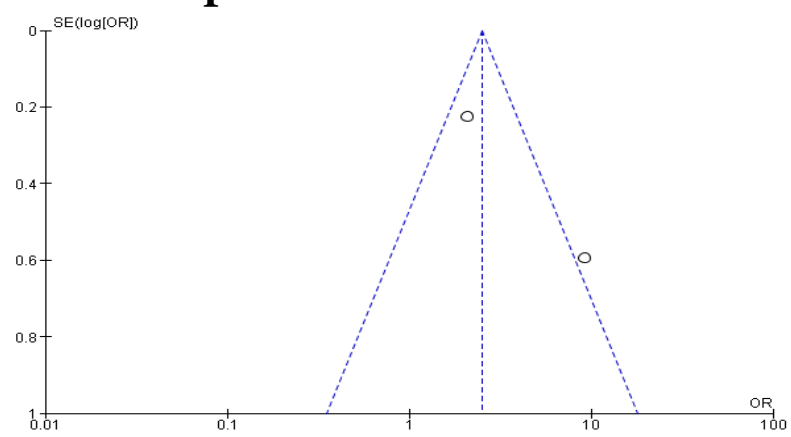

Figure 6. The funnel plot of having sex with CSW on the incidence of HIV

Figure 6 shows that there was a publication bias marked by an asymmetry in the right and left plots. The left plot was near from standard error by 0.2 and the right plot had standard error by o.6. Bias also occurred from the unbalanced distance between studies, both the right and left sides, where studies on the right side had more distance than studies on the left side of the funnel plot.

\section{Sexually transmitted infection}

There were 5 cross-sectional articles as a source of a meta-analysis of the effect of STI on the incidence of HIV among male military personnel in the world

Table 4. The effect of STIs on the incidence of HIV

\begin{tabular}{llccc}
\hline \multicolumn{1}{c}{ Author (year) } & Country & aOR & 95\% CI & p \\
\hline Nelson et al. (1993) & Thailand & 3.36 & 2.46 to 4.60 & $<0.001$ \\
Szwarcwald et al.(2005) & Brazil & 2.76 & 1.18 to 6.45 & 0.020 \\
Szwarcwald et al. (2011) & Brazil & 2.53 & 1.20 to 5.36 & 0.015 \\
Khamboonruang et al. (1996) & Thailand & 5.96 & 3.84 to 9.26 & $<0.001$ \\
Harbertson et al. (2013) & Rwanda & 3.40 & 1.50 to 7.60 & 0.003 \\
\hline
\end{tabular}

\section{b. Forest plot}

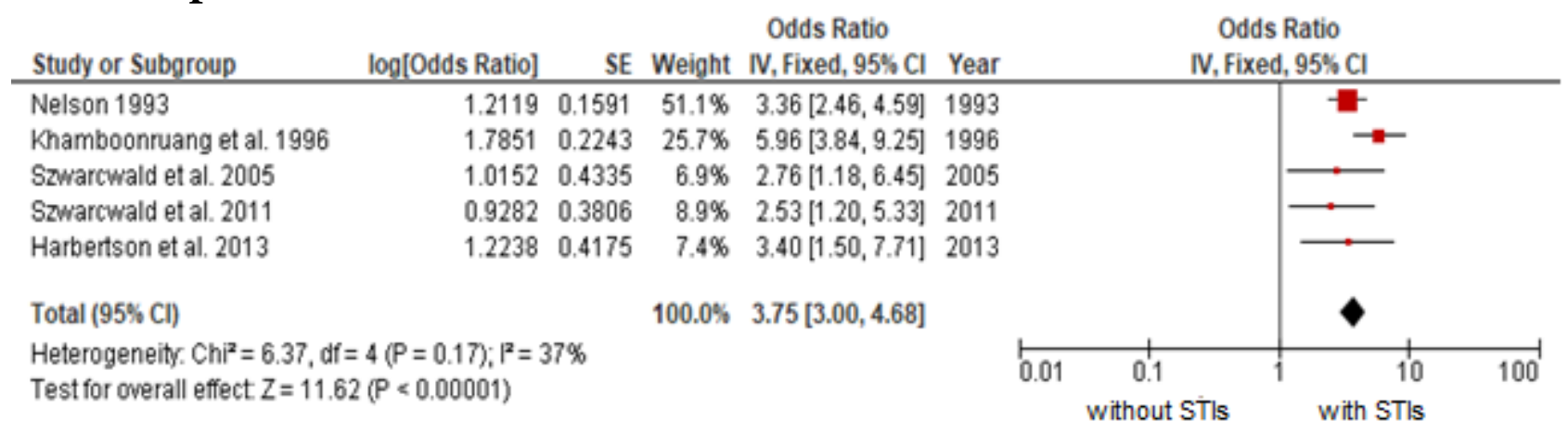

Figure 7. The forest plot of STI on the incidence of HIV 
Based on the result of the forest plot, sexually transmitted infection (STI) could increase the incidence of HIV in male military personnel by 3.75 times compared to those without STI. The result was statistically significant $(\mathrm{p}<0.001) . \mathrm{I}^{2}=37 \%$ showed homogeneous data distribution (fixed-effect model).

\section{c. Funnel plot}

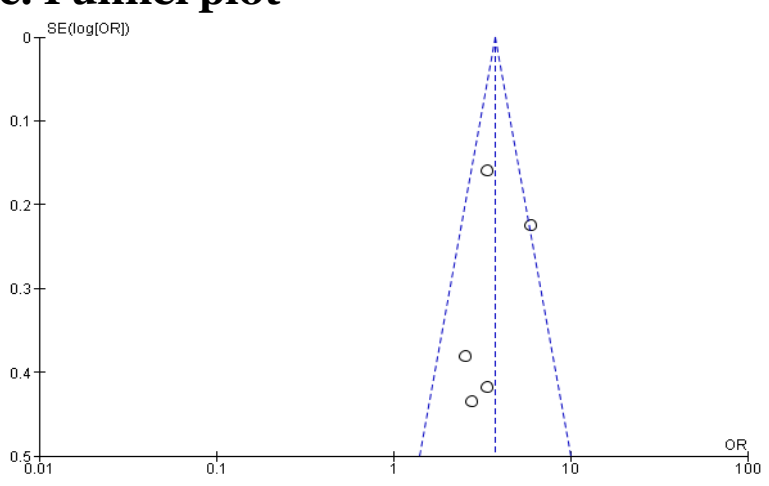

Figure 8. The funnel plot of STI on the incidence of HIV

Figure 8 shows that there was a publication bias marked by an asymmetry in the right and left plots. There were 4 plots that tended to be on the left and 1 plot was on the right.

\section{DISCUSSION}

This systematic review and meta-analysis study took the theme of the risk factors of HIV among male military personnel in the world. The independent variables that were related to the risk factors analyzed were sexual orientation status, number of sexual partners, having sex with CSW, and STI. A study that discusses data on HIV prevalence in the military is still considered important because of its rarity. The number of published and accessible studies is still small because some data are considered confidential or sensitive (Whiteside et al., 2006). Most of the statistical results reported were in the percentage or crude odds ratio (cOR), where the study did not control for confounding factors.

Confounding factors that affected the correlation or effect of the contamination with a disease estimated by the study was not the same as the correlation or effect that actually occurred on the target population. The result of the study was not valid (incorrect) (Murti, 2018). This systematic study and meta-analysis study used study that controlled confounding factors. It could be seen from the terms of study inclusion. It used multivariate analysis. The statistical result was aOR.

The combined estimation of the correlation of each risk factor to the incidence of HIV was processed using RevMan 5.3 application with the generic inversevariance method. This method was used to analyze the data in the form of rate, timeto-event, hazard ratio, ordinal scale, adjusted estimate, the difference of mean, or ratio of mean.

The results of the systematic study and meta-analysis were presented in the form of forest plots and funnel plots. Forest plot was a graphical representation of a meta-analysis that mentioned several important tables and information including the average score, standard deviation, odds/risk ratio, and the number of study participants (Akobeng, 2005). A funnel plot was a plot that illustrated the estimated size of the effects of each study on the estimated accuracy which was usually a standard error. In this case, the study with large size (a lot of samples) and high precision (confident interval) would reach the actual effect (Simmonds, 2015).

Funnel plots could be assessed from the asymmetry of the study from seeing the number of points on the right and left compared to the standard error and the balance of the number of studies on the right and left (Simmonds, 2015). 
The previous study showed that HIV had a direct correlation with the frequency of sexual relations, sexual orientation, unsafe sexual behavior, and the use of injection drugs (Puspita et al., 2018). Positive HIV positive status also increased in the individuals with higher income, age $\geq 24$ years, ignorance of HIV status, lack of support from health workers, multiple sexual partners, and the STIs (Subaeti et al., 2018).

\section{Men who have Sex with Men}

The result of the forest plot showed that MSM sexual orientation status could increase the incidence of HIV in male military personnel by 9.37 times compared to heterosexual orientation status (normal).

The high prevalence of HIV came from South and Southeast Asian MSM groups, Latin America, and the Caribbean (van Griensven et al., 2009). MSM has potentially become one of the links to transmit HIV. It is because MSM is heterosexual men who have sexual orientation to the opposite and the same sex (bisexual). MSM will be the medium to transmit HIV through sexual relations in their communities (Firdaus et al., 2013). Based on a study conducted by Wati et al. (2018), the probability of the occurrence of HIV in the MSM group who had a tendency to change partners was 2.9 times compared to the MSM who had a spouse.

\section{The number of the sexual partner}

Based on the result of the forest plot, the number of sexual partners $>10$ to the incidence of HIV could increase the incidence of HIV in male military personnel by 3.05 times compared to those who had a spouse.

If one sex partner is contaminated with HIV, the HIV virus will be carried in vaginal fluid or semen and pre-cum (Firdaus et al., 2013). Moreover, if there is an injury in the sex organs, the risk of contaminating with HIV from an infected person in a case is much higher than in controls (Ambro-sioni et al., 2011).

\section{Having sex with CSW}

The result of the forest plot showed that having sex with CSW could increase the incidence of HIV in male military personnel by 3.93 times compared to not having sex with CSW.

Sexual buying behavior of commercial sex workers (CSW), both men and women were at risk of contaminating with HIV. CSWis sex service providers. In addition, they have many sexual relations. Therefore, the risk of contaminating with HIV is very high (Firdaus et al., 2013).

\section{Sexual Transmitted Infection (STI)}

The result of the forest plot showed that STI could increase the incidence of HIV in male military personnel by 3.75 times compared to male military personnel without STI.

Inflammation and ulcers in people with STI increased the susceptibility to HIV infection. The damage to the mucosal barrier made it easy for the HIV virus to enter the blood vessels. In addition, STI facilitated the HIV virus to live in the genital tract and recruited inflammatory cells of the HIV virus into the genital tract (Laksana and Lestari, 2010).

MSM, sexually transmitted infections, sexual partners $>10$ increased the incidence of HIV among male military personnel, and it was statistically significant. Sex with CSWs increased the incidence of HIV among male military personnel, but it was not statistically significant.

\section{FUNDING AND SPONSORSHIP}

This study used personal funds from the main researcher.

\section{AUTHOR CONTRIBUTION}

Ayu Anulus was the main researcher who chose the topic, searched, and collected the 
data of the study. Bhisma Murti played a role in analyzing the data of the study. Hanung Prasetya played a role in reviewing the document.

\section{CONFLICT OF INTEREST}

There was no conflict of interest.

\section{ACKNOWLEDGMENT}

We give the best gratitude to the electronic database providers of PubMed, Scopus, Springer Link, ScienceDirect, and Clinical key.

\section{REFERENCE}

Akobeng AK (2005). Understanding systematic reviews and meta-analysis. Arch Dis Child, 90(8): 845-848. https://doi.org/10.1136/adc.2004.058230

Ambrosioni J, Calmy A, Hirschel B (2011). HIV treatment for prevention. JIAS, 14(1): 28. https://doi.org/10.1186/1758-2652-14-28.

Courtney LP, Goco N, Woja J, Farris T, Cummiskey C, Smith E, Chun HM (2017). HIV prevalence and behavioral risk factors in the Sudan People's Liberation Army: Data from South Sudan. PLoS ONE, 12(11): e0187689. https://doi.org/10.1371/journal.pone.0187689

Firdaus S, Agustin H, Baiturrahmah FKM (2013). Faktor Risiko Kejadian HIV pada Komunitas LSL (Lelaki Seks dengan Lelaki) Mitra Yayasan Lantera Minangkabau Sumatera Barat. Jurnal Kesehatan Komunitas, 2(2): 94-99. Retrieved from http://jurnal.htp.ac.id/index.php/keskom/article/dow nload/52/41

Harbertson J, Grillo M, Zimulinda E, Murego C, Brodine S, May S, Shaffer R (2013). HIV seroprevalence, associa- ted risk behavior, and alcohol use among male Rwanda Defense Forces military personnel. AIDS and Behavior, 17(5): 1734-1745. Retrieved from https://doi.org/10.1007/s10461-012o343-6

Hoover KW, Tao KL, Peters PJ (2017). Nationally representative prevalence estimates of gay, bisexual, and other men who have sex with men who have served in the U.S. military. PLoS ONE, 12(8): 1-9. https://doi.org/10.1371/journal.pone.0182222

ILO (2018). The impact of HIV and AIDS on the world of work: global estimates. Switzerland: International Labour Organization. Retrieved from https://www.ilo.org/wcmsp5/groups/public/---dgreports/---dcomm/--publ/documents/publication/wcms_630166.pdf

JadraninZ, Suljagić V, Todorovic V, Trkuljić M, Vucetić D. (2012). HIV/AIDS and other sexually transmitted infections among military members of the Armed Forces of Serbia. Vojnosanit Pregl, 69(1): 43-48. https://doi.org/10.2298/vsp1201043j.

Johar SA, Demartoto A, Wekadigunawan CS (2018). Factors Associated with women's decision to become commercial sex workers in Banjarsari, Surakarta, Central Java. J Epidemiol Public Healt, 3(1): 72-82. https://doi.org/10.26911/jepublichealth.2018.03.01.06

Kenny L, Carballo M, Spiegel P, Harris B, Kayembe P, El-bushra J, FossA. (2010). HIV/AIDS, security and conflict: making the connections Vulnerable mobile populations overlooked. FMR, 10: 1-32.

Khamboonruang C, Beyrer C, Natpratan C, Keawvichit R, Wongworapat K, Eiumtrakul S, Nelson KE (1996). Human 
immunodeficiency virus infection and self-treatment for sexually transmitted diseases among northern Thai men. STD. 23: 264-269. https://doi.org/10.1097/00007435-19960700000003 .

Laksana ASD, Lestari DWD (2010). Communication between dual-DSP in active power factor correction of arc welding inverter power source. Jilin Daxue Xuebao, 40(1): 384-388.

Murti B (2018). Prinsip dan metode riset epidemiologi (Edisi V). Surakarta: Bintang Fajar Offset.

Nelson KE, Celentano DD, Suprasert S, Wright N, Eiumtrakul S, Tulvatana S, Theetranont C (1993). Risk Factors for HIV Infection Among Young Adult Men in Northern Thailand. JAMA, 270(8): 955-960. https://doi.org/10.1001/jama.1993.03510080059032

Puspita, IF, Budihastuti UR, Widyaningsih V (2018). Psychological and Social Determinants of HIV: Path Analysis Evidence from Jepara, Central Java. J Health Promot Behav, 1(2019): 4354. https://doi.org/https://doi.org/10.26911/thejhpb.2019.04.01.05

Simmonds M (2015). Quantifying the risk of error when interpreting funnelplots. Syst Rev, 4(1):24. https://doi.org/10.1186/s13643-015-0004-8

Subaeti T, Demartoto A, Murti B (2018). Socioeconomic Factors and Sexual Behavior Associated with HIV Infection in Population, in Kebumen District, Central Java. J Health Promot Behav, 3(1): 56-65. https://doi.org/- 10.26911/thejhpb.2018.03.01.06

Szwarcwald CL, Andrade CLT de, Pascom ARP, Fazito E, Pereira GFM, Penha IT da (2011). HIV-related risky practices among Brazilian young men, 2007. Cad Saude Publica, 27(1), s19-s26. https://doi.org/10.1590/s0102-311X2011001300003

Szwarcwald CL, de Carvalho MF, Barbosa Júnior A, Barreira D, Speranza FAB, de Castilho EA (2005). Temporal trends of HIV-related risk behavior among Brazilian military conscripts, 1997-2002. Clinics (São Paulo), 60(5), 367-374. https://doi.org/10.159o/S1807-59322005000500004

UNAIDS (1998). AIDS and the military: UNAIDS point of view. In UNAIDS. Retrieved from http://data.unaids.org/publications/irc-pubo5/militarypv_en.pdf

UNAIDS (2018). UNAIDS Data 2018. Programme on HIV/AIDS, 1-376. Retrieved from http://www.unaids.org/sites/default/files/media_asset/unaids-data-2018_en.pdf\%oA

Wati EE, Lubis R, Rochadi RK (2018). The Effects of Multiple Sexual Partners and Condoms Use on the Incidence of HIV in Men Having Sex with Men. J Health Promot Behav, 3(3): 150-154. https://doi.org/10.26911/thejhpb.2018.03.03.02

Whiteside A, de Waal A, Gebre-Tensae T (2006). AIDS, security and the military in Africa: A sober appraisal. African Affairs, 105(419): 201-218. https://doi.org/10.1093/afraf/adi104 